\title{
Clinically significant red cell antigen phenotypes in Fayoum university hospital blood donors.
}

\author{
Shahira Morsy Elshafie (1), Ghada M. Ezzat Ahmed (2), and Ahmed Ali \\ Badie Sady (3) \\ (1)Professor of Clinical Pathology, Faculty of Medicine Fayoum University \\ (2)Assistant Professor of Clinical Pathology, Faculty of Medicine Fayoum \\ University \\ (3)Clinical Pathology Department, Faculty of Medicine Fayoum \\ University
}

Corresponding author: prof. Shahira M. Elshafie

E-mail address: dr.elshafie@gmail.com

Tel: 01114962049

BACKGROUND: Human red blood cells (RBC) bear numerous cell surface structures that can be recognized as antigens by the immune system of individuals who lack that particular structure and elicit an immune response which is termed alloimmunization. The incidence of alloimmunization is high in chronically transfused patients, such as those with hemoglobinopathies, myelodysplastic syndromes, chronic renal disease and others.The objective of this study was to determine clinically significant red cell antigen phenotypes in a sample of Fayoum University blood donors.

\section{STUDY DESIGN AND}

METHODS: A total of 60 Egyptian blood donors attending Fayoum University Hospital Blood Bank were analyzed. Antigens detection were done using DiaMed-ID microtyping system.

Results: Dce phenotype was encountered in 19(31.67\%) subjects, followed by DCce which was found in $17(28.33 \%)$ cases. The third most common phenotype was De demonstrated in 7(11.67\%) of the study group, then DEe phenotype which was represented in $5(8.33 \%)$ donors.Both the DcEe and de antigen phenotypes were found in 4 cases each with a frequency of $6.67 \%$, while the least $\mathrm{Rh}$ system antigen phenotypes were $\mathrm{DCcEe}$ in 2(3.33\%) donors, DE and DCc in only one (1.67\%) subject each.

Conclusion: The study showed that identification of the pattern of clinically significant patterns among Fayoum donors is a step in the prevention of alloimmunization and subsequent hemolytic complications in transfused patients albeit the chronic ones.

Keywords: Phenotyping, Alloimmunization.

\section{Introduction:}

Red blood cell transfusions have been the standard of care for treating anemia for more than 100 years now, with little evidence that they improve clinical outcomes ${ }^{1}$. The standard transfusion trigger for many years had been a hemoglobin of $10 \mathrm{~g} / \mathrm{dL}$ or even higher. ${ }^{2}$ This arbitrary 
trigger has been lowered gradually to a hemoglobin level of 6 to $8 \mathrm{~g} / \mathrm{dL}$ because studies showed that blood transfusions are associated with worse outcomes in patients with anemia due to illness or bleeding, compared with simple supportive measures such as hydration. ${ }^{3}$

Red blood cells (RBCs), or erythrocytes, are the most common type of blood cell and the vertebrate organism's principal means of delivering oxygen $\left(\mathrm{O}_{2}\right)$ to the body tissues via the blood flow through the circulatory system. ${ }^{4}$ Red cell antigens can be defined as 'An inherited character of the red cell surface, detected by a specific alloantibody. ${ }^{5}$ The aim of this work was to study clinically significant red cell antigen phenotypes in a sample of Fayoum University blood donors. Results will be used to conclude an extended red cell matching policy in patients presenting to Fayoum University Hospital requiring repeated blood transfusions.

\section{Materials and Methods: Recruitment:}

This study was conducted on 60 subjects attending the Fayoum University Hospital blood bank. Informed consent was obtained from each subject or their legal guardians before enrollment in the study Donors were recruited with special emphasis on inclusion criteria of donors recommended by the national standards for donor selection criteria in Egypt, which, generally, considers age, medical history, and infections.

\section{Laboratory investigations:}

All donors were routinely tested for $\mathrm{ABO}$ and $\mathrm{RhD}$ blood grouping: By gel card method using Diamed system ABO-Rh/Reverse Grouping), And red blood cell antigens phenotyping: to detect their minor blood group antigens using Diamed neutral cassettes that contain gel matrix.

\section{Results:}

Our study was carried out on 60 Egyptian blood donors attending Fayoum blood bank to determine their major and minor blood group antigens. Fifty eight (96.67\%) were males and only two $(3.33 \%)$ were females with a male to female ratio 29:1. Their ages ranged from 18 to 48 years with mean age 33 years \pm 7.5 . ABO blood group was done for all subjects and showed the following: $33.33 \%$ representing 20 subjects exhibited blood group B, while (31.67\%) 19 donors showed blood group A. Blood group O was demonstrated in 12 cases (20\%) of the study group and $\mathrm{AB}$ blood group was found in 9 subjects (15\%).Regarding the $\mathrm{RhD}$ of the subjects we found that: 56(93.33\%) of the donors were $\mathrm{RhD}$ positive while only $4(6.67 \%)$ were $\mathrm{RhD}$ negative. As regards the minor blood group antigens analyzed among our studied group, the highest antigen detected was small e antigen which was represented in 58/60 cases (96.7\%). The second most common minor red cell antigen encountered was small s which was found in $49 / 60$ subjects $(81.7 \%)$, this was followed by the small $\mathrm{c}$ antigen in $43 / 60$ donors (71.7\%). Both Jka \& $\mathrm{N}$ minor group antigens were encountered in $29 / 60$ cases $(48.3 \%)$, then came the $\mathrm{S}$ antigen which represented 22/60 of the studied donors (36.7\%). 20/60 subjects $(33.3 \%)$ of our study group exhibited $\mathrm{C}$ and $\mathrm{Jkb}$ red cell antigens, while 12 cases (20\%) showed the E blood group antigen followed by the $\mathrm{M}$ antigen exhibited in 9 donors(15\%). 
ISSN: 2536-9482 (Online) Fayoum University Medical Journal Elshafie et al., 2020,5(1), 41-45

The least antigens detected were Fya \& K representing 8/60(13.3\%) and 6/60 (10\%) subjects respectively while Duffy (Fyb) was not detected in any subject.

Table (1): Frequency of the different major blood groups of the studied cases:

\begin{tabular}{||c|c|c|c||}
\hline $\begin{array}{c}\text { Major blood group } \\
\text { systems }\end{array}$ & Type & No. & \% \\
\hline \hline \multirow{3}{*}{ ABO Blood group } & $\mathrm{B}$ & 20 & 33.33 \\
\cline { 2 - 4 } & $\mathrm{A}$ & 19 & 31.67 \\
\cline { 2 - 4 } & $\mathrm{O}$ & 12 & 20 \\
\cline { 2 - 4 } & $\mathrm{AB}$ & 9 & 15 \\
\hline \multirow{2}{*}{ RhD } & Positive & 56 & 93.33 \\
\cline { 2 - 4 } & Negative & 4 & 6.67 \\
\hline
\end{tabular}

Table (1): Frequency of red cell minor antigens:

\begin{tabular}{||l|c|c||}
\hline \multicolumn{1}{|c|}{ Antigen } & Count & $\%$ \\
\hline \hline $\mathrm{E}$ & 58 & $96.7 \%$ \\
\hline $\mathrm{S}$ & 49 & $81.7 \%$ \\
\hline $\mathrm{C}$ & 43 & $71.7 \%$ \\
\hline $\mathrm{Jka}$ & 29 & $48.3 \%$ \\
\hline $\mathrm{N}$ & 29 & $48.3 \%$ \\
\hline $\mathrm{S}$ & 22 & $36.7 \%$ \\
\hline $\mathrm{C}$ & 20 & $33.3 \%$ \\
\hline $\mathrm{Jkb}$ & 20 & $33.3 \%$ \\
\hline $\mathrm{E}$ & 12 & $20.0 \%$ \\
\hline $\mathrm{M}$ & 9 & $15.0 \%$ \\
\hline Fya & 8 & $13.3 \%$ \\
\hline $\mathrm{K}$ & 6 & $10.0 \%$ \\
\hline Fyb & 0 & $0.0 \%$ \\
\hline
\end{tabular}

Table (2): Frequency of Rh system antigen phenotypes.

\begin{tabular}{|l|c|c|}
\hline \multicolumn{1}{|c|}{ Phenotype } & Count & \% \\
\hline \hline Dce & 19 & 31.67 \\
\hline DCce & 17 & 28.33 \\
\hline De & 7 & 11.67 \\
\hline Dee & 5 & 8.33 \\
\hline DcEe & 4 & 6.67 \\
\hline De & 4 & 6.67 \\
\hline DCcEe & 2 & 3.33 \\
\hline
\end{tabular}




\begin{tabular}{|l|l|l|}
\hline DE & 1 & 1.67 \\
\hline DCc & 1 & 1.67 \\
\hline
\end{tabular}

Discussion:

This study was carried on 60 Egyptian blood donors attending Fayoum University Hospital Blood Bank to determine their major and minor blood group antigens and their phenotypes. Knowledge on the degree of homogenecity between blood donors and receipients can be valuable for the design of a tailored extended cross matching policy for blood transfusion specially in the low resources blood banks.

Any antibody reacts specifically with the antigen which stimulated its production. According to this, an antigen could be identified by using its corresponding antibody, so we used the gel card method to detect the donors major blood groups (ABO and $\mathrm{RhD}$ ) and minor blood group antigens namely Rh system, Kell, Kidd, Duffy and MNS systems using the procedure which is based on the principle of red cell agglutination. It utilizes column agglutination technology, comprised of gel and reagent contained in a column ${ }^{6}$.

Fifty eight $(96.67 \%)$ were males and only two(3.33\%) were females with a male to female ratio 29:1.

Amongst the Rh system in our study, the highest antigen detected was small e (96.7\%) followed by D (93.33\%), c (71.7\%), C $(33.3 \%)$ and the least was E (20\%).

Makroo et al. ${ }^{7}$ reported that the most common Rh antigen observed in his study was small e (98\%) followed by D (93.6\%), $\mathrm{C}(87 \%), \mathrm{c}(58 \%)$ and the least was $\mathrm{E}$ antigen (20\%). Also in north India Lamba et $a \boldsymbol{l}^{8}$. found that the small e represented $(99 \%)$ of the donors followed by D (93\%), C $(85.1 \%), \mathrm{c}(62.3 \%)$ and finally E $(21.5 \%)$. Another study by Kahar and Patel ${ }^{9}$ revealed the highest $\mathrm{Rh}$ antigen detected was small e (100\%) followed by D and C (84.34 and $81.74 \%$ respectively).

Regarding the Kell system $\mathrm{K}$ antigen was demonstrated in $10 \%$ of our study group. Agarwal et al. ${ }^{10}$ reported that $\mathrm{K}$ antigen represented $1.97 \%$ of the studied donors while Lamba et al. ${ }^{8}$ found the $\mathrm{K}$ antigen in $2.8 \%$ of the cases. Kahar and Patel ${ }^{9}$ reported that the $\mathrm{K}$ antigen was demonstrated in $6.09 \%$ of donors and Makroo et al. ${ }^{7}$ found $3.5 \%$ of the donors were $\mathrm{K}$ positive.

The kidd system phenotypes expressed were $\mathrm{jk}(\mathrm{a}+\mathrm{b}-)$ and $\mathrm{jk}(\mathrm{a}-\mathrm{b}-)$ in $33.3 \%$ each, $\mathrm{jk}(\mathrm{a}-\mathrm{b}+)$ in $18.33 \%$ and $\mathrm{jk}(\mathrm{a}+\mathrm{b}+)$ in $15 \%$ of the studied donors.

A study by Agarwal et $\boldsymbol{a l} .{ }^{10}$ reported that $\mathrm{Jk}(\mathrm{a}+\mathrm{b}+)$ was the most common Kidd blood group phenotype and the same was found by Kahar and Patel ${ }^{9}$, and Musa et al. ${ }^{11}$ with a percentage of $(52.17 \%, 50.4 \%$ and $43 \%$ respectively).

Regarding Duffy blood group system the most found phenotype was Fy(a-b-) representing $(86.67 \%)$ of Duffy phenotypes in the studied donors.

Kahar and Patel ${ }^{9}$ reported that Fy(a-b-) was the dominant phenotype and its percentage was $(48.69 \%)$ while in a study by Makroo et $\boldsymbol{a l}{ }^{7}$ the most common duffy phenotype was Fy $(a+b-)$. Agarwal et al. ${ }^{10}$ found the most common Duffy phenotype was Fy(a+b-)

Amongst the blood donors studied in our research the most occurred MNSs system phenotype was $\mathrm{M}-\mathrm{N}+$ and $\mathrm{S}-\mathrm{s}+$ representing (43.33\% and 53.33\% respectively) and overall the M-N-S-s+ phenotype occurred the most in the studied cases.Other studies done by Makroo et al. ${ }^{7}$, Agarwal et al ${ }^{10}$, 
Kahar and Patel ${ }^{9}$, and Musa et al., ${ }^{11}$ reported that the most common $\mathrm{MN}$ phenotype was $\mathrm{M}+\mathrm{N}+$ and regarding the $\mathrm{S}$ phenotype both Agarwal et al. ${ }^{10}$ and Kaha and Patel $^{9}$ found that S-s+ was the most observed phenotype with an incidence of $(47.63 \%$ and $66.96 \%)$ respectively.

\section{References:}

1- Schmidt PJ, Ness PM. Hemotherapy: from bloodletting magic to transfusion medicine. Transfusion. 2006;46:166-168).

2- McIntyre L, Hebert PC, Wells G, et al. Is a restrictive transfusion strategy safe for resuscitated and critically ill trauma patients?J Trauma. 2004;57:563-8.

3- Carson JL, Grossman BJ, Kleinman S, et al. Red blood cell transfusion: a clinical practice guideline from the AABB*. Ann Intern Med. 2012;157:49-58.

4- Westhoff CM. The Rh blood group system in review: a new face for the next decade. Transfusion 2004; 44:1663-1673.

5- Daniels $G$ and Bromilow I. An introduction to blood group. In: Essential Guide to Blood Groups (2 ${ }^{\text {nd }}$ Edition). Blackwell Pub. UK. 2010a P: 1-6.

6- Weiss E and Chizhevsky V. Implementation of gel testing for antibody screening and identification in a community hospital, a 3- year experience. Lab Med. 2005; 36(8):489-492.

\section{7- Makroo RN, Bhatia A, Gupta R, Phillip} J. Prevalence of Rh, Duffy, Kell, Kidd \& MNSs blood group antigens in the Indian blood donor population. The Indian journal of medical research 2013; 137:521-6.

8- Lamba D, Kaur R, Basu S. Clinically Significant Minor Blood Group Antigens amongst North Indian Donor Population. Advances in Hematology Volume 2013; Article ID 215454, 5 pages
9- Kahar M and Patel R. Phenotype frequencies of blood group systems (Rh, Kell, Kidd, Duffy, MNS, P, Lewis, and Lutheran) in blood donors of south Gujarat, India. Asian J Transfus Sci. 2014; 8(1): 5155.

10- Agarwal N, Thapliyal RM, Chatterjee K. Blood group phenotype frequencies in blood donors from a tertiary care hospital in north India. Blood research 2013; 48:51-54.

11- Musa R, Ahmed S, Hashim H, Ayob Y, Asidin N, Choo P, Al-Joudi F. Red cell phenotyping of blood from donors at the National blood center of Malaysia. Asian J Transfus Sci. 2012; 6(1): 3-9. 